\title{
Anti-Osteoporotic Mechanisms of Polyphenols Elucidated Based on In Vivo Studies Using Ovariectomized Animals
}

\author{
Yoshimi Niwano ${ }^{1, * \mathbb{C}}$, Hidetsugu Kohzaki ${ }^{1}$, Midori Shirato ${ }^{2}$, Shunichi Shishido ${ }^{2}$ and Keisuke Nakamura ${ }^{2}$ \\ 1 Faculty of Nursing, Shumei University, 1-1 Daigaku-cho, Yachiyo, Chiba 276-0003, Japan; \\ kohzaki@mailg.shumei-u.ac.jp \\ 2 Department of Advanced Free Radical Science, Tohoku University Graduate School of Dentistry, \\ 4-1 Seiryo-machi, Aoba-ku, Sendai 980-8575, Japan; midori.shirato.c8@tohoku.ac.jp (M.S.); \\ shunichi.shishido.b2@tohoku.ac.jp (S.S.); keisuke.nakamura.e5@tohoku.ac.jp (K.N.) \\ * Correspondence: yoshimi.niwano.b2@tohoku.ac.jp; Tel.: +81-47-411-7862
}

check for updates

Citation: Niwano, Y.; Kohzaki, H.; Shirato, M.; Shishido, S.; Nakamura, K. Anti-Osteoporotic Mechanisms of Polyphenols Elucidated Based on In Vivo Studies Using Ovariectomized Animals. Antioxidants 2022, 11, 217. https://doi.org/10.3390/ antiox11020217

Received: 23 November 2021 Accepted: 21 January 2022

Published: 23 January 2022

Publisher's Note: MDPI stays neutral with regard to jurisdictional claims in published maps and institutional affiliations.

Copyright: (C) 2022 by the authors. Licensee MDPI, Basel, Switzerland. This article is an open access article distributed under the terms and conditions of the Creative Commons Attribution (CC BY) license (https:// creativecommons.org/licenses/by/ $4.0 /)$.

\begin{abstract}
Polyphenols are widely known for their antioxidant activity, i.e., they have the ability to suppress oxidative stress, and this behavior is mediated by the autoxidation of their phenolic hydroxyl groups. Postmenopausal osteoporosis is a common health problem that is associated with estrogen deficiency. Since oxidative stress is thought to play a key role in the onset and progression of osteoporosis, it is expected that polyphenols can serve as a safe and suitable treatment in this regard. Therefore, in this review, we aimed to elucidate the anti-osteoporotic mechanisms of polyphenols reported by in vivo studies involving the use of ovariectomized animals. We categorized the polyphenols as resveratrol, purified polyphenols other than resveratrol, or polyphenol-rich substances or extracts. Literature data indicated that resveratrol activates sirtuin 1, and thereafter, suppresses osteoclastogenic pathways, such as the receptor activator of the nuclear factor kappa B (RANK) ligand (RANKL) pathway, and promotes osteoblastogenic pathways, such as the wingless-related MMTV integration site pathway. Further, we noted that purified polyphenols and polyphenol-rich substances or extracts exert anti-inflammatory and/or antioxidative effects, which inhibit RANKL/RANK binding via the NF- $\mathrm{KB}$ pathway, resulting in the suppression of osteoclastogenesis. In conclusion, antioxidative and anti-inflammatory polyphenols, including resveratrol, can be safe and effective for the treatment of postmenopausal osteoporosis based on their ability to regulate the imbalance between bone formation and resorption.
\end{abstract}

Keywords: polyphenol; postmenopausal osteoporosis; ovariectomized animals; bone health

\section{Introduction}

The World Health Organization (WHO) has defined osteoporosis as a disease characterized by low bone mass and bone tissue microarchitectural deterioration that leads to enhanced bone fragility and a consequent increase in fracture risk [1]. Postmenopausal osteoporosis is a common health problem associated with estrogen deficiency [2]. Recent studies have shown that oxidative stress plays a pivotal role in the onset and progression of this disease [3], and the associated excessive generation of reactive oxygen species (ROS) has negative impacts on bone remodeling owing to osteoblast dysfunction and osteoclast activation [4,5]. Oxidative stress may enhance the expression of genes involved in inflammation, bringing about the development of postmenopausal osteoporosis [6]. Since the ROS overproduction can be associated with nuclear factor kappa B (NF-kB)-mediated inflammation [7,8], we also focused on the anti-inflammatory action of polyphenols as well as their antioxidative action. It is expected that polyphenols, with antioxidative and anti-inflammatory potential, would serve as a safe and suitable remedy for postmenopausal osteoporosis. This is consistent with epidemiological reports showing that dietary flavonoids, which are bioactive polyphenols, ameliorate bone health $[9,10]$. 
However, the fundamental mechanisms of action of these polyphenols have not yet been fully elucidated.

Aside from polyphenols' antioxidant activity, they possess pro-oxidant potential. Typical examples of pro-oxidant activity are the antibacterial activity of catechins [11] and the cytocidal action of plant polyphenols on cancer cells [12]. Nuclear factor E2-related factor 2 (Nrf2) plays a crucial role in protecting cells, tissues, and organs on the basis of various genes encoding antioxidant proteins [13-15]. Upon ROS generation by polyphenols, cells could activate the Nrf2 pathway independently of polyphenols' antioxidant activity. This idea drove us to focus on in vivo studies of polyphenols.

The purpose of this study was to comprehensively review the anti-osteoporotic effects of polyphenols in postmenopausal women. Since detailed information on this matter would be limited in human intervention studies, studies in which ovariectomized animals were used as postmenopausal osteoporosis models were screened in PubMed using the keywords "polyphenol AND ovariectomy". The screening was further narrowed down to studies that were conducted within the last two decades (2002-2021) in which polyphenols were orally administered.

\section{Resveratrol}

Reportedly, resveratrol, a well-known sirtuin 1 (SIRT1) agonist, shows a life-span prolonging effect in various organisms [16-20], and it plays a beneficial role in neural, cardiovascular, and orthopedic diseases [21]. Besides such effects, it also exerts favorable effects on osteoporosis in ovariectomized rats and mice, as summarized in Table 1. Several studies have demonstrated that the oral administration of resveratrol in ovariectomized rodents mitigates estrogen deficiency-induced bone loss [22-28], and with respect to its anti-osteoporotic mechanisms, it has been demonstrated that resveratrol not only promotes osteoblast differentiation but also suppresses osteoclast differentiation [22,24,28]. It has been proposed that microRNAs (miRNAs/miRs) play a pivotal role in estrogen deficiencyinduced osteoporosis prevention. Resveratrol suppresses the expression of miR $3383 p$, which serves as a negative regulator of osteogenic differentiation in bone marrow stromal cells [29], and enhances the expression of miR-92b-3p, which inhibits osteoclast proliferation and stimulates osteoblast differentiation by suppressing the activity of the NADPH oxidase 4 (Nox4)/nuclear factor kappa B (NF- $\mathrm{kB}$ ) signaling pathway [26]. Additionally, the administration of resveratrol to ovariectomized rats downregulates the expression of Nox enzymes, which are responsible for the production of ROS, resulting in the mitigation of estrogen deficiency-induced alveolar bone loss [27].

Given that resveratrol is an SIRT1 agonist, it can be concluded that SIRT1 lies at the center of its molecular mechanism. Orally administered resveratrol increases osteoblast differentiation in ovariectomized rats via the activation of SIRT1 and the subsequent suppression of NF- $\mathrm{KB}$ activity [22]. It has also been reported that the management of osteoporosis in resveratrol-treated ovariectomized rats could be achieved by activating two signaling pathways-namely, the SIRT1 and wingless-related MMTV integration site (Wnt) pathways [28]. The receptor activator of NF- $\mathrm{kB}$ ligand (RANKL), which is released by osteoblasts and is essential for osteoclast development and activation, and its receptor, RANK, signal the activation of NF- $\mathrm{kB}$, resulting in accelerated osteoclast differentiation [30-32]. However, the activation of SIRT1 by resveratrol can suppress RANKL-induced NF- $k B$ activity $[22,28]$. The Wnt signaling pathway not only promotes osteoblast proliferation but also attenuates their apoptosis [33], and this is further enhanced by SIRT1 [34,35]. Figure 1 summarizes the molecular-level mechanism of osteoporosis management, centered on SIRT1, in ovariectomized rodents using resveratrol. Resveratrol can suppress the RANKL/RANK signaling pathway in osteoclast precursors, leading to a decrease in osteoclast differentiation. It can also enhance the Wnt signaling pathway in osteoblast precursors, leading to increased osteoblast differentiation. 
Table 1. Beneficial effects of oral resveratrol on osteoporosis in ovariectomized rodents.

\begin{tabular}{|c|c|c|c|c|}
\hline \multirow{2}{*}{$\begin{array}{c}\text { Reference, Year of } \\
\text { Publication, and Animal } \\
\text { Species with Age at OVX }\end{array}$} & \multirow{2}{*}{ Dosage } & \multirow{2}{*}{$\begin{array}{l}\text { Major Improved } \\
\text { Parameter(s) }\end{array}$} & \multicolumn{2}{|c|}{ Mode of Action } \\
\hline & & & Overview & Molecular Level \\
\hline $\begin{array}{l}\text { [22] } 2014 \\
\text { Rats aged } 3 \text { months }\end{array}$ & $\begin{array}{c}5,25 \text {, and } 45 \mathrm{mg} / \mathrm{kg} / \text { day } \\
\text { for } 8 \text { weeks starting at } \\
1 \text { week after OVX }\end{array}$ & $\begin{array}{c}\text { BMD of lumbar } \\
\text { vertebrae (L3) and } \\
\text { femur }\end{array}$ & $\begin{array}{l}\text { Increased osteoblast } \\
\text { differentiation }\end{array}$ & $\begin{array}{l}\text { Activation of SIRT1 and } \\
\text { subsequent suppression of } \\
\text { NF- } \kappa \text { B activity }\end{array}$ \\
\hline $\begin{array}{l}\text { [23] } 2014 \\
\text { Rats aged 3-4 months }\end{array}$ & $\begin{array}{c}20,40 \text {, and } 80 \mathrm{mg} / \mathrm{kg} / \text { day } \\
\text { for } 12 \text { weeks starting at } \\
2 \text { weeks after OVX }\end{array}$ & BMD of femur & - & - \\
\hline $\begin{array}{l}\text { [24] } 2020 \\
\text { Rats aged 10-12 weeks }\end{array}$ & $\begin{array}{c}10,20 \text {, and } 40 \mathrm{mg} / \mathrm{kg} / \text { day } \\
\text { for } 8 \text { weeks starting at } \\
1 \text { week after OVX }\end{array}$ & $\begin{array}{l}\text { BMD of the lumbar } \\
\text { vertebrae (L3) and the } \\
\text { right distal femur-tibia } \\
\text { bone region }\end{array}$ & $\begin{array}{l}\text { Promotion of osteoblast } \\
\text { differentiation and } \\
\text { suppression of osteoclast } \\
\text { differentiation via } \\
\text { autophagy regulation }\end{array}$ & - \\
\hline $\begin{array}{l}\text { [25] } 2020 \\
\text { Rats aged } 3 \text { months }\end{array}$ & $\begin{array}{c}5,15 \text {, and } 45 \mathrm{mg} / \mathrm{kg} / \text { day } \\
\text { for } 12 \text { weeks starting at } \\
3 \text { days after OVX }\end{array}$ & BMD of femur & Estrogen-like activity & - \\
\hline $\begin{array}{l}\text { [26] } 2020 \\
\text { Rats aged } 6 \text { months }\end{array}$ & $\begin{array}{c}50,100, \text { and } \\
200 \mathrm{mg} / \mathrm{kg} / \text { day for } \\
12 \text { weeks after OVX }\end{array}$ & BMD of femur & - & $\begin{array}{c}\text { Suppression of cathepsin } \mathrm{K} \\
\text { expression and the } \\
\text { Nox4/NF- } \mathrm{B} \text { signaling } \\
\text { pathway through the } \\
\text { elevated expression of } \\
\text { miR-92b-3p }\end{array}$ \\
\hline $\begin{array}{l}\text { [27] } 2020 \\
\text { Adult rats }\end{array}$ & $\begin{array}{c}10 \mathrm{mg} / \mathrm{kg} / \text { day for } \\
140 \text { days after OVX } \\
\text { (sacrificed } 28 \text { days after } \\
\text { experimental periodontitis } \\
\text { initiation) }\end{array}$ & Alveolar bone mass & - & $\begin{array}{c}\text { Downregulation of NADPH } \\
\text { oxidase levels }\end{array}$ \\
\hline $\begin{array}{l}\text { [28] } 2021 \\
\text { Rats aged } 3 \text { months }\end{array}$ & $\begin{array}{l}80 \mathrm{mg} / \mathrm{kg} / \text { day for } \\
8 \text { weeks starting at } \\
8 \text { weeks after OVX }\end{array}$ & $\mathrm{BMC}$ and $\mathrm{BMD}$ of femur & $\begin{array}{c}\text { Stimulation of } \\
\text { osteogenesis and } \\
\text { inhibition of } \\
\text { osteoclastogenesis }\end{array}$ & $\begin{array}{c}\text { Activation of sirtuin } 1 \\
\text { (SIRT1) and wingless-related } \\
\text { MMTV integration site } \\
\text { (Wnt) pathways }\end{array}$ \\
\hline
\end{tabular}

OVX, ovariectomy; BMD, bone mineral density; BMC, bone mineral content; —, not clearly described. Unless otherwise stated, resveratrol was administered by oral gavage.

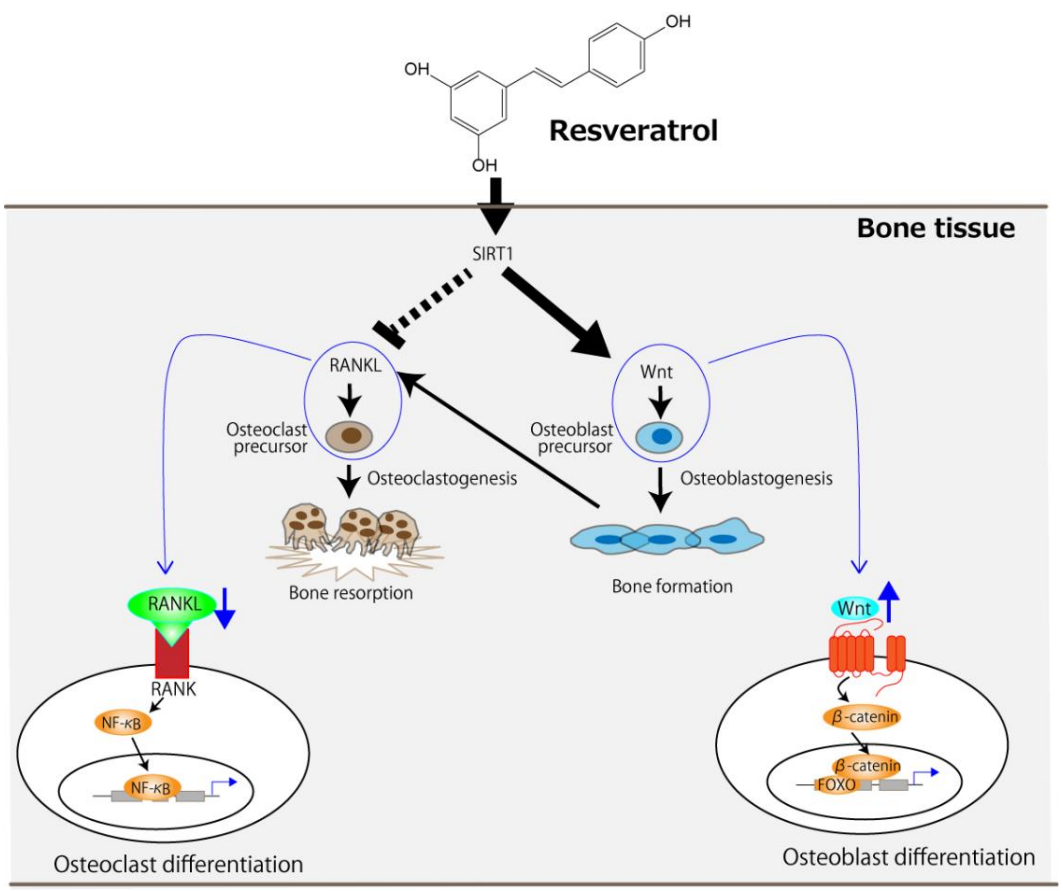

Figure 1. The proposed molecular-level mechanism underlying the improvement of OVX-induced osteoporosis by resveratrol centered on SIRT1. The arrows and the dotted line indicate stimulation and suppression, respectively. FOXO, forkhead box protein. 


\section{Purified Polyphenolic Compounds Other Than Resveratrol}

The beneficial effects of purified polyphenolic compounds other than resveratrol on osteoporosis in ovariectomized rodents are summarized in Table 2. Phloridzin, an apple polyphenol, along with oleuropein, tyrosol, and hydroxytyrosol, all of which are olive oil polyphenols, elicit protective effects on bone loss in ovariectomized + inflammationprovoked rats, probably by lowering the risk of inflammation-induced osteopenia via their antioxidant activity [36-38]. It has also been observed that both oleuropein and hydroxytyrosol prevent bone loss in ovariectomized mice by regulating oxidative stress via their antioxidant effects [39]. Further, phytoestrogens, such as genistein and 8-prenylnaringenin, also prevent bone loss and improve bone biomechanical strength in ovariectomized rats via an agonistic action on estrogen receptors [40], and reportedly, luteolin, a plant flavonoid, significantly enhances bone mineral density (BMD) and bone mineral content (BMC), while mitigating bone strength loss in ovariectomized mice by reducing both osteoclast differentiation and function [41].

Table 2. Beneficial effects of oral purified-polyphenolic compounds other than resveratrol on osteoporosis in ovariectomized rodents.

\begin{abstract}
Reference, Year of Publication,
and Animal Species with Age at OVX
\end{abstract}

\section{Dosage Major Improved Parameter(s)}

Mode of Action

\begin{tabular}{|c|c|c|c|}
\hline \multicolumn{4}{|c|}{ Phloridzin (an apple polyphenol) } \\
\hline $\begin{array}{l}\text { [36] } 2005 \\
\text { Rats aged } 6 \text { months }\end{array}$ & $\begin{array}{c}\text { Oral administration with a diet } \\
\text { supplemented with } 0.25 \% \\
\text { phloridzin for } 80 \text { days after OVX. } \\
\text { Inflammation was induced by a } \\
\text { subcutaneous injection of } \\
\text { magnesium silicate } 3 \text { weeks } \\
\text { before necropsy. }\end{array}$ & BMD of femur & $\begin{array}{c}\text { Improving inflammatory marker } \\
\text { levels and decreasing bone } \\
\text { resorption }\end{array}$ \\
\hline \multicolumn{4}{|c|}{ Oleuropein (an olive oil polyphenol) } \\
\hline $\begin{array}{l}\text { [37] } 2006 \\
\text { Rats aged } 6 \text { months }\end{array}$ & $\begin{array}{c}2.5,5,10, \text { and } 15 \mathrm{mg} / \mathrm{kg} / \text { day for } \\
100 \text { days after OVX }\end{array}$ & BMD of femur & Reducing inflammatory state \\
\hline \multicolumn{4}{|c|}{ Tyrosol and hydroxytyrosol (olive oil polyphenols) } \\
\hline $\begin{array}{l}\text { [38] } 2008 \\
\text { Rats aged } 6 \text { months }\end{array}$ & $\begin{array}{l}\text { Oral administration with a diet } \\
\text { supplemented with either } 0.017 \% \\
\text { tyrosol or } 0.017 \% \text { hydroxytyrosol } \\
\text { for } 84 \text { days after OVX; } \\
\text { Three weeks before the end of the } \\
\text { investigation (d } 63 \text { ), inflammation } \\
\text { was provoked by a subcutaneous } \\
\text { injection of magnesium silicate. }\end{array}$ & BMD of femur & $\begin{array}{l}\text { Possibly lowering the risk of } \\
\text { inflammation-induced osteopenia } \\
\text { via their antioxidant activity }\end{array}$ \\
\hline \multicolumn{4}{|c|}{ Oleuropein and hydroxytyrosol (olive oil polyphenols) } \\
\hline $\begin{array}{c}\text { [39] } 2011 \\
\text { Mice aged } 6 \text { weeks }\end{array}$ & $\begin{array}{c}10 \mathrm{mg} / \mathrm{kg} \text { at } 3 \text {-day intervals for } \\
28 \text { days after OVX }\end{array}$ & BMD of femur & $\begin{array}{l}\text { Regulating oxidative stress via } \\
\text { their antioxidant effects }\end{array}$ \\
\hline \multicolumn{4}{|c|}{ Genistein (GEN) and 8-prenylnaringenin (8PN) } \\
\hline $\begin{array}{l}\text { [40] } 2008 \\
\text { Rats aged } 3 \text { months }\end{array}$ & $\begin{array}{c}6 \text { and } 60 \mathrm{mg} \text { GEN/kg/day or } 6.8 \\
\text { and } 68 \mathrm{mg} 8 \mathrm{PN} / \mathrm{kg} / \text { day for } \\
3 \text { months after OVX }\end{array}$ & BMD of tibia & Acting as phytoestrogens \\
\hline \multicolumn{4}{|c|}{ Luteolin } \\
\hline $\begin{array}{c}{[41] 2011} \\
\text { Mice aged } 9 \text { weeks }\end{array}$ & $\begin{array}{c}5 \text { and } 20 \mathrm{mg} / \mathrm{kg} / \text { day for } 30 \text { days } \\
\text { starting at } 1 \text { week after OVX }\end{array}$ & $\mathrm{BMD}$ and $\mathrm{BMC}$ of femur & $\begin{array}{l}\text { Reducing both osteoclast } \\
\text { differentiation and function }\end{array}$ \\
\hline
\end{tabular}

OVX, ovariectomy; BMD, bone mineral density; BMC, bone mineral content. Unless otherwise stated, the polyphenols were administered by oral gavage.

Based on these studies, we focused on the relationship between the anti-inflammatory effect of polyphenol compounds as well as their osteoporosis-alleviating effects. As a hypothesis for the relationship between estrogen deficiency, bone loss, and inflammation in osteoporosis, it has been suggested that pro-inflammatory cytokines, such as interleukin-1 
(IL-1), tumor necrosis factor-alpha (TNF- $\alpha$ ), and IL-6, are the primary mediators of accelerated bone loss during menopause [42]. The increased production of such pro-inflammatory cytokines is associated with the binding of RANKL to RANK, which results in osteoclastic bone resorption during estrogen deficiency.

\section{Polyphenol-Rich Substances or Extracts}

The beneficial effects of polyphenol-rich substances or extracts are summarized in Table 3. Tea, a popular beverage that is consumed worldwide, is prepared from the processed leaves of the plant Camellia sinensis using either hot or cold water. The results of some studies have indicated that green tea containing epicatechin, epicatechin-3-gallate, epigallocatechin, and epigallocatechin-3-gallate has bone-health improvement effects. It has also been reported that green tea polyphenols (GTPs) in drinking water mitigate bone loss as well as bone microarchitecture deterioration in middle-aged ovariectomized rats [43-45]. These beneficial effects of GTPs can be attributed to their antioxidant potential. For example, the glutathione peroxidase produced by osteoblasts protects against ROS [46], and simultaneously decreases oxidative stress damage in bone tissue. Further, safflower seed (Carthamus tinctorius L.) has been clinically used in Korea; specifically, defatted safflower seed powder containing polyphenols partially prevents OVX-induced bone loss in rats by stimulating osteoblast proliferation [47]. As a putative phytoestrogen, polyphenolrich Du-Zhong (Eucommia ulmoides Oliv.) cortex extract prevents OVX-induced bone loss in rats [48]. Moreover, Du-Zhong, which is rich in polyphenolic compounds, such as lignans, phenolic acids, and flavonoids, is a kidney-tonifying herbal medicine used in China, and possibly, its extract stimulates osteoblast activity and inhibits osteoclast resorption via estrogen receptor $\beta$. A relatively short-term study ( 8 days) involving the use of dietary purified blueberry polyphenols, which are rich in anthocyanin, revealed that polyphenols enhance calcium absorption in ovariectomized rats [49]. As an interesting anti-osteoporotic mechanism, it was recently reported that arecanut (Areca catechu L.) seed polyphenol promotes bone formation by altering gut microbiota along with controlling inflammatory reactions [50]. The seed has also been used in osteoporosis therapy in the field of Chinese medicine. Polyphenol-rich heat-treated melon extract is also a typical example of a substance with antioxidant activity that illustrates the protective effect of polyphenols on OVX-induced bone loss [51]. Specifically, melon extract protects against the deterioration of bone strength as well as bone mineralization in ovariectomized rats, probably owing to its potent antioxidant activity.

Table 3. Beneficial effects of oral polyphenol-rich substances or extracts on osteoporosis in ovariectomized rodents.

\begin{tabular}{|c|c|c|c|}
\hline $\begin{array}{c}\text { Reference, Year of } \\
\text { Publication, and Animal } \\
\text { Species with Age at OVX }\end{array}$ & Dosage & $\begin{array}{l}\text { Major Improved } \\
\text { Parameter(s) }\end{array}$ & Mode of Action \\
\hline \multicolumn{4}{|c|}{ Green tea (Camellia sinensis) polyphenols (GTPs) containing epigallocatechin-3-gallate } \\
\hline $\begin{array}{l}\text { [43] } 2008 \\
\text { Rats aged } 14 \text { months }\end{array}$ & $\begin{array}{c}0.1 \% \text { and } 0.5 \%(w / v) \text { GTP } \\
\text { aqueous solution for } 16 \text { weeks } \\
\text { after OVX }\end{array}$ & BMD of femur & $\begin{array}{c}\text { An increase in antioxidant } \\
\text { capacity and/or a decrease in } \\
\text { oxidative stress damage }\end{array}$ \\
\hline $\begin{array}{l}\text { [44] } 2009 \\
\text { Rats aged } 14 \text { months }\end{array}$ & $\begin{array}{c}0.1 \% \text { and } 0.5 \%(w / v) \text { GTP } \\
\text { aqueous solution for } 16 \text { weeks } \\
\text { after OVX }\end{array}$ & $\begin{array}{l}\text { BMD of femur; } \\
\text { Bone microarchitecture of tibia }\end{array}$ & $\begin{array}{c}\text { An increase in antioxidant } \\
\text { capacity and/or a decrease in } \\
\text { oxidative stress damage }\end{array}$ \\
\hline $\begin{array}{l}\text { [45] } 2019 \\
\text { Rats aged } 6 \text { months }\end{array}$ & $\begin{array}{l}0.15 \%, 0.5 \%, 1.0 \% \text {, and } 1.5 \% \\
(w / v) \text { GTP aqueous solution } \\
\text { for } 3 \text { and } 6 \text { months after OVX }\end{array}$ & $\begin{array}{l}\text { Bone microarchitecture and } \\
\text { mechanical properties of tibia, } \\
\text { femur, and lumbar vertebrae } \\
\text { (L3) }\end{array}$ & $\begin{array}{l}\text { GTP's antioxidative and } \\
\text { anti-inflammatory actions }\end{array}$ \\
\hline
\end{tabular}


Table 3. Cont.

\begin{tabular}{|c|c|c|c|}
\hline $\begin{array}{c}\text { Reference, Year of } \\
\text { Publication, and Animal } \\
\text { Species with Age at OVX }\end{array}$ & Dosage & $\begin{array}{l}\text { Major Improved } \\
\text { Parameter(s) }\end{array}$ & Mode of Action \\
\hline \multicolumn{4}{|c|}{ Defatted safflower (Carthamus tinctorius L.) seed powder containing lignans and flavones } \\
\hline $\begin{array}{l}\text { [47] } 2002 \\
\text { Rats aged } 12 \text { weeks }\end{array}$ & $\begin{array}{c}290 \mathrm{~g} / \mathrm{kg} \text { diet for } 4 \text { weeks } \\
\text { starting at } 1 \text { week after OVX }\end{array}$ & Bone mass of proximal tibia & $\begin{array}{l}\text { Possibly stimulating } \\
\text { osteoblast proliferation }\end{array}$ \\
\hline \multicolumn{4}{|c|}{ Polyphenol-rich Du-Zhong (Eucommia ulmoides Oliv.) cortex extract containing lignans, phenolic acid, and flavonoids } \\
\hline $\begin{array}{l}\text { [48] } 2009 \\
\text { Rats aged } 3 \text { months }\end{array}$ & $\begin{array}{c}100,300 \text {, and } 500 \mathrm{mg} / \mathrm{kg} / \text { day } \\
\text { for } 16 \text { weeks starting at } \\
4 \text { weeks after OVX }\end{array}$ & BMD of femur & $\begin{array}{l}\text { Possibly stimulating } \\
\text { osteoblast activity and } \\
\text { inhibiting osteoclast } \\
\text { resorption through } \operatorname{Er} \beta\end{array}$ \\
\hline \multicolumn{4}{|c|}{ Polyphenol-rich blueberry (Vaccinium corymbosum) extract containing anthocyanins, phenolic acids, plavan-3-ols, and flavonols } \\
\hline $\begin{array}{l}\quad[49] 2020 \\
\text { Rats aged } 5 \text { months }\end{array}$ & $\begin{array}{l}75,350 \text {, and } 1000 \mathrm{mg} \text { total } \\
\text { polyphenols } / \mathrm{kg} / \text { day for } \\
8 \text { days starting at } 12 \text { days } \\
\text { after OVX }\end{array}$ & Calcium absorption & - \\
\hline \multicolumn{4}{|c|}{ Arecanut (Areca catechu L.) seed polyphenol containing proanthocyanidin b2, procyanidin b1, catechin, etc. } \\
\hline $\begin{array}{c}{[50] 2021} \\
\text { Rats weighing } 190 \pm 10 \mathrm{~g}\end{array}$ & $\begin{array}{c}400 \text { and } 800 \mathrm{mg} / \mathrm{kg} / \text { day for } \\
90 \text { days starting at } 30 \text { days } \\
\text { after OVX }\end{array}$ & $\begin{array}{l}\text { Trabecular microstructure of } \\
\text { femur }\end{array}$ & $\begin{array}{c}\text { Promoting bone formation by } \\
\text { altering gut microbiota along } \\
\text { with controlling inflammatory } \\
\text { reaction }\end{array}$ \\
\hline \multicolumn{4}{|c|}{ Polyphenol-rich heat-treated melon (Cucumis melo L.) extract } \\
\hline $\begin{array}{l}\text { [51] } 2019 \\
\text { Rats aged } 7 \text { weeks }\end{array}$ & $\begin{array}{c}1 \mathrm{~mL} \text { of the extract } \\
3 \text { times/day for } 4 \text { weeks } \\
\text { starting at } 8 \text { weeks after OVX }\end{array}$ & $\begin{array}{l}\text { Bone strengths of femur; BMC } \\
\text { and BMD of whole body, } \\
\text { femur, and lumbar vertebrae } \\
4-6\end{array}$ & $\begin{array}{l}\text { Potent antioxidant activity } \\
\text { leading to protection from the } \\
\text { decline in bone strength, } \\
\text { mineralization, and } \\
\text { metabolism }\end{array}$ \\
\hline
\end{tabular}

OVX, ovariectomy; BMD, bone mineral density; BMC, bone mineral content; - , not clearly described. Unless otherwise stated, substances or extracts were administered by oral gavage.

\section{Studies in Which Polyphenols Did Not Show Any Beneficial or Positive Effects on Bone Health in Ovariectomized Animals}

Some studies have shown that polyphenols do not exert any positive effects on bone health in ovariectomized animals (Table 4). In one study, genistein, administered once daily as an oral supplement for five months, did not show any beneficial effect on the tibia in ovariectomized rats used as a model for postmenopausal bone loss [52]. In another study, the synergistic administration of quercetin, genistein, resveratrol, and vitamin $\mathrm{D}_{3}$ via feeding for 4 weeks failed to protect bone loss in ovariectomized aged rats [53]. Even though the feeding administration of polyphenol-rich blueberry extract showed increased calcium absorption in ovariectomized rats [49], a purified extract of blueberry polyphenols or lyophilized blueberries administered via oral gavage for 90 days failed to improve BMD, bone microarchitecture, or other mechanical properties of the bone in ovariectomized rats [54]. The results of this study emphasized that most surrogate measures of bone strength (e.g., BMD and calcium absorption) are only partially correlated with bone mechanical properties and fracture. In another study, the feeding administration of extra virgin olive oil polyphenols for 12 weeks regulated uterine estrogen response marker genes in an E2-agonistic manner but did not mitigate estrogen ablation-induced bone loss [55]. Relatively old animals were used in three of the four studies presented in Table 4; thus, waning metabolic activity due to senescence could explain the poor osteogenic effect of the polyphenols. A review on the bioavailability of phytoestrogens using rodent models [56] reported that data should be interpreted with caution because of the large interspecies variability observed in the metabolism of phytoestrogens by rodent, e.g., limited intestinal 
absorption as well as rapid excretion. These are limitations of animal studies involving rats and mice. Thus, when interpreting the mode of actions, care must be taken when extrapolating the results corresponding to animal models to humans.

Table 4. Studies in which oral polyphenols and polyphenol-rich extracts did not show any beneficial effects on bone health in ovariectomized rodents.

\begin{tabular}{|c|c|c|}
\hline $\begin{array}{l}\text { Reference, Year of Publication, and } \\
\text { Animal Species with Age at OVX }\end{array}$ & Dosage & Observations \\
\hline \multicolumn{3}{|c|}{ Genistein } \\
\hline $\begin{array}{c}{[52] 2013} \\
\text { Rats aged 7, 16, and } 22 \text { months }\end{array}$ & $\begin{array}{c}\text { A pellet/day ( } 485 \text { and } 970 \mu \mathrm{g} \\
\text { genistein/pellet) for } 5 \text { months after OVX }\end{array}$ & $\begin{array}{l}\text { No significant effects on cancellous or } \\
\text { cortical bone mass or architecture of tibia }\end{array}$ \\
\hline \multicolumn{3}{|c|}{ Mixure of quercetin (QUE), genistein (GEN), resveratrol (RES), and vitamin $\mathrm{D}_{3}(\mathrm{VD})$} \\
\hline $\begin{array}{l}{[53] 2018} \\
\text { Aged rats (retired breeder) }\end{array}$ & $\begin{array}{l}1000 \mathrm{mg} \text { QUE/kg diet, } 500 \mathrm{mg} \text { GEN/kg } \\
\text { diet, } 200 \mathrm{mg} \text { RES/ } / \mathrm{kg} \text { diet, and } 2400 \mathrm{IU} \\
\text { VD/kg diet for } 4 \text { weeks after OVX; } \\
2000 \mathrm{mg} \text { QUE/ } \mathrm{kg} \text { diet, } 1000 \mathrm{mg} \text { GEN/kg } \\
\text { diet, } 400 \mathrm{mg} \text { RES/ } / \mathrm{kg} \text { diet, and } 2400 \mathrm{IU} \\
\text { VD/ } \mathrm{kg} \text { diet, for } 4 \text { weeks after OVX }\end{array}$ & $\begin{array}{l}\text { No significant effects on BMD of whole } \\
\text { femur or L4 or L5 }\end{array}$ \\
\hline
\end{tabular}

Purified extract of blueberry (Vaccinium corymbosum) polyphenols or lyophilized blueberries

50,250 , or $1000 \mathrm{mg}$ total polyphenols $/ \mathrm{kg} /$ day for purified

[54] 2021

Rats aged 5 months blueberry polyphenols or $50 \mathrm{mg}$ total polyphenols $/ \mathrm{kg} /$ day for lyophilized whole blueberries, for 90 days starting 1 month after OVX
Insignificant effects on BMD and bone mechanical properties

Extra virgin olive (Olea europaea var. Koroneiki) oil total polyphenolic fraction (TPF) containing oleocanthal, oleacein, and ligstroside as major polyphenols

\begin{tabular}{ccc}
\hline [55] 2014 & $800 \mathrm{mg}$ TPF $/ \mathrm{kg}$ diet for 12 weeks \\
after OVX & $\begin{array}{c}\text { No significant effects on the bone loss of } \\
\text { Rats aged 12 months }\end{array}$ \\
\hline
\end{tabular}

OVX, ovariectomy; BMD, bone mineral density. Unless otherwise stated, substances or extracts were administered by oral gavage.

\section{Conclusions}

The bone loss in ovariectomized animals is likely due to accelerated osteoclastogenic activity induced by a deficiency in estrogen, leading to the imbalance of bone turnover in which resorption outpaces formation [57]. It would be presumed that polyphenols other than resveratrol mainly counteract the accelerated osteoclast activity. Anti-osteoporotic mechanisms of antioxidative and anti-inflammatory polyphenols are schematically represented in Figure 2. Besides the direct action on osteoclasts, circulating polyphenols and/or their metabolites can suppress oxidative stress caused by the NF- $\mathrm{kB}$ activation of the monocyte-macrophage system under estrogen deficiency, alleviating pro-inflammatory cytokine production. Subsequently, the RANKL/RANK signaling pathway is suppressed, leading to the mitigation of osteoclastogenesis. On the contrary, evidence of an effect of polyphenols on osteoblast activity is scarce, and only two in vitro studies have reported such an effect $[47,48]$.

To confirm the idea proposed in Figure 2, we think that information on the absorption, distribution, metabolism, and elimination (ADME) of the target polyphenols would be essential. However, instead of conducting a complete ADME study, which may be timeconsuming and expensive, a simple pharmacokinetic study can also be of significance. For instance, a liver S9 fraction assay combined with a Caco-2 permeability assay and a liquid chromatography-mass spectrometry analysis can be useful [58] for the examination of the involvement of circulating metabolites in the observed action of their mother polyphenols in vivo and for the identification of their target sites of action. Future studies should also investigate the role of polyphenol pro-oxidant properties in improving bone 
health. If ROS produced by polyphenols, via the oxidation of phenolic hydroxyl moiety and the reduction of dissolved oxygen, have the potential to activate the Nrf2 pathway, it would provide a new perspective to the in vivo effects of polyphenols.

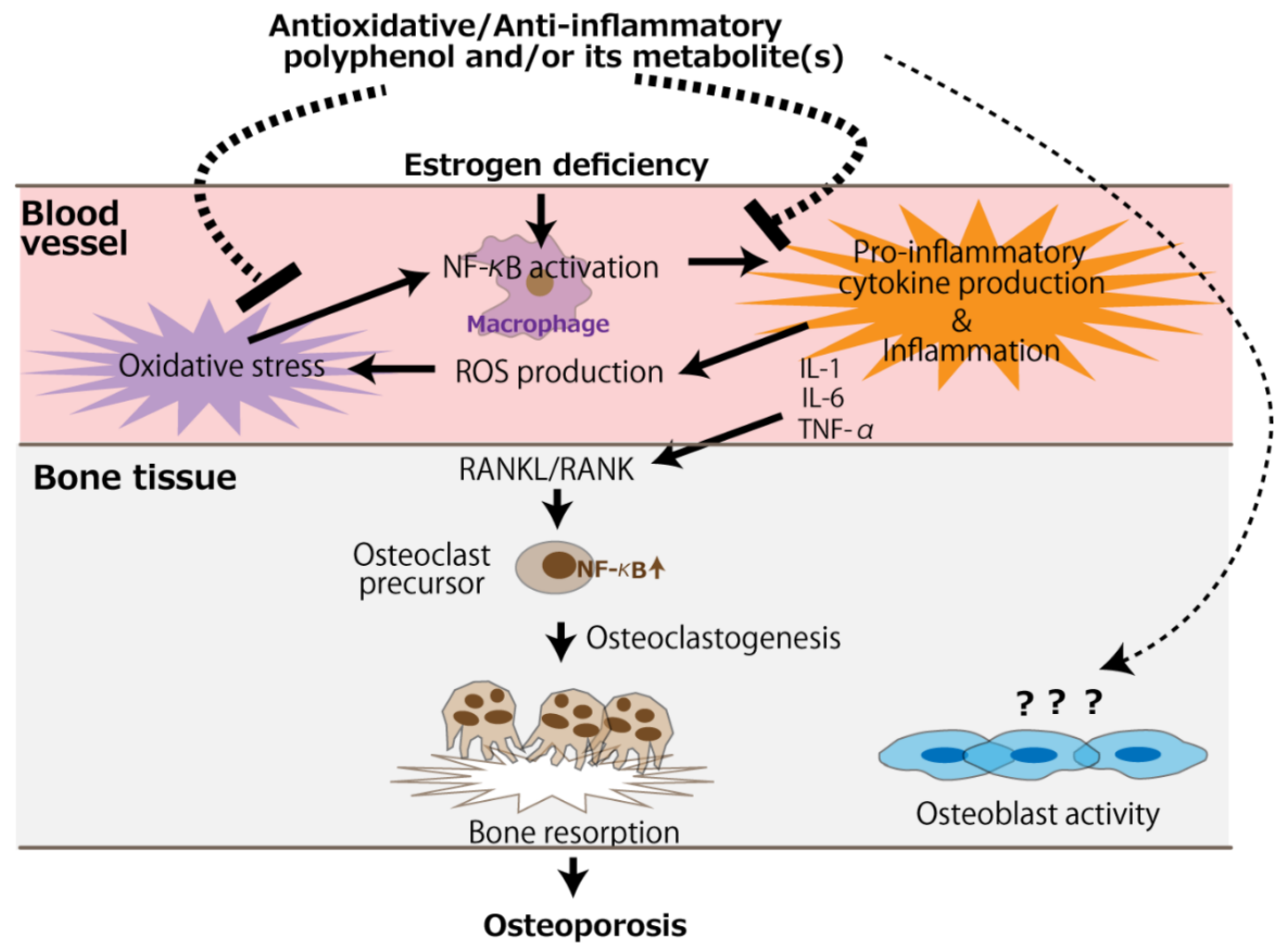

Figure 2. The putative mechanism of the antioxidative and anti-inflammatory effects of polyphenols for the prevention of postmenopausal osteoporosis. The arrows and dotted line indicate stimulation and suppression, respectively. ROS, reactive oxygen species.

Finally, to further confirm polyphenols' ability to prevent bone fragility fractures in postmenopausal females with osteoporosis, we think that more studies using aged animals focusing on bone microarchitecture and the mechanical properties of the bone-rather than surrogate measures of bone strength (e.g., BMD and calcium absorption)-are needed.

Author Contributions: Conceptualization, Y.N., H.K. and K.N.; methodology, Y.N., M.S. and S.S.; writing—original draft preparation, Y.N., H.K. and K.N.; writing—review and editing, M.S. and S.S.; funding acquisition, Y.N. All authors have read and agreed to the published version of the manuscript.

Funding: This research was funded by JSPS KAKENHI Grant Number JP20K09996.

Conflicts of Interest: Shirato, Shishido, and Nakamura are members of an academia-industry collaboration laboratory at the Tohoku University Graduate School of Dentistry, which received funding from Luke Co. Ltd. (Sendai, Japan). This academia-industry collaboration was examined and approved by the Conflict of Interest Management Committee at Tohoku University. Luke Co. Ltd. and the grant funder had no role in the conception of the study design, data collection and interpretation, or the decision to submit the work for publication.

\section{References}

1. Christiansen, C. Consensus development conference: Prophylaxis and treatment of osteoporosis. Am. J. Med. 1991, 90, 107-110.

2. Manolagas, S.C. From estrogen-centric to aging and oxidative stress: A revised perspective of the pathogenesis of osteoporosis. Endocr. Rev. 2010, 31, 266-300. [CrossRef]

3. Zhou, Q.; Zhu, L.; Zhang, D.; Li, N.; Li, Q.; Dai, P.; Mao, Y.; Li, X.; Ma, J.; Huang, S. Oxidative stress-related biomarkers in postmenopausal osteoporosis: A systematic review and meta-analyses. Dis. Markers 2016, 2016, 7067984. [CrossRef] 
4. Callaway, D.A.; Jiang, J.X. Reactive oxygen species and oxidative stress in osteoclastogenesis, skeletal aging and bone diseases. J. Bone Miner. Metab. 2015, 33, 359-370. [CrossRef]

5. Vrtačnik, P.; Zupan, J.; Mlakar, V.; Kranjc, T.; Marc, J.; Kern, B.; Ostanek, B. Epigenetic enzymes influenced by oxidative stress and hypoxia mimetic in osteoblasts are differentially expressed in patients with osteoporosis and osteoarthritis. Sci. Rep. 2018, 8 , 16215. [CrossRef]

6. Mohamad, N.V.; Ima-Nirwana, S.; Chin, K.Y. Are Oxidative Stress and Inflammation Mediators of Bone Loss Due to Estrogen Deficiency? A Review of Current Evidence. Endocr. Metab. Immune Disord. Drug. Targets 2020, 20, 1478-1487. [CrossRef]

7. Abdul Rahim, R.; Jayusman, P.A.; Muhammad, N.; Mohamed, N.; Lim, V.; Ahmad, N.H.; Mohamad, S.; Abdul Hamid, Z.A.; Ahmad, F.; Mokhtar, N.; et al. Potential antioxidant and anti-inflammatory efects of Spilanthes acmella and its health beneficial effects: A review. Int. J. Environ. Res. Public Health 2021, 18, 3532. [CrossRef]

8. Nani, A.; Murtaza, B.; Sayed Khan, A.; Khan, N.A.; Hichami, A. Antioxidant and anti-Inflammatory potential of polyphenols contained in Mediterranean diet in obesity: Molecular mechanisms. Molecules 2021, 26, 985. [CrossRef]

9. Hardcastle, A.C.; Aucott, L.; Reid, D.M.; Macdonald, H.M. Associations between dietary flavonoid intakes and bone health in a Scottish population. J. Bone Miner. Res. 2011, 26, 941-947. [CrossRef]

10. Welch, A.; MacGregor, A.; Jennings, A.; Fairweather-Tait, S.; Spector, T.; Cassidy, A. Habitual flavonoid intakes are positively associated with bone mineral density in women. J. Bone Miner. Res. 2012, 27, 1872-1878. [CrossRef]

11. Arakawa, H.; Maeda, M.; Okubo, S.; Shimamura, T. Role of hydrogen peroxide in bactericidal action of catechin. Biol. Pharm. Bull. 2004, 27, 277-281. [CrossRef]

12. Khan, H.Y.; Zubair, H.; Faisal, M.; Ullah, M.F.; Farhan, M.; Sarkar, F.H.; Ahmad, A.; Hadi, S.M. Plant polyphenol induced cell death in human cancer cells involves mobilization of intracellular copper ions and reactive oxygen species generation: A mechanism for cancer chemopreventive action. Mol. Nutr. Food Res. 2014, 58, 437-446. [CrossRef] [PubMed]

13. Leonard, M.O.; Kieran, N.E.; Howell, K.; Burne, M.J.; Varadarajan, R.; Dhakshinamoorthy, S.; Porter, A.G.; O’Farrelly, C.; Rabb, H.; Taylor, C.T. Reoxygenation-specific activation of the antioxidant transcription factor Nrf2 mediates cytoprotective gene expression in ischemia-reperfusion injury. FASEB J. 2006, 20, 2624-2626. [CrossRef]

14. Shelton, L.M.; Park, B.K.; Copple, I.M. Role of Nrf2 in protection against acute kidney injury. Kidney Int. 2013, 84, 1090-1095. [CrossRef]

15. Smith, R.E.; Tran, K.; Smith, C.C.; McDonald, M.; Shejwalkar, P.; Hara, K. The role of the Nrf2/ARE antioxidant system in preventing cardiovascular diseases. Diseases 2016, 4, 34. [CrossRef] [PubMed]

16. Howitz, K.T.; Bitterman, K.J.; Cohen, H.Y.; Lamming, D.W.; Lavu, S.; Wood, J.G.; Zipkin, R.E.; Chung, P.; Kisielewski, A.; Zhang, L.L.; et al. Small molecule activators of sirtuins extend Saccharomyces cerevisiae lifespan. Nature 2003, 425, 191-196. [CrossRef] [PubMed]

17. Viswanathan, M.; Kim, S.K.; Berdichevsky, A.; Guarente, L. A role for SIR-2.1 regulation of ER stress response genes in determining C. elegans life span. Dev. Cell 2005, 9, 605-615. [CrossRef] [PubMed]

18. Bauer, J.H.; Goupil, S.; Garber, G.B.; Helfand, S.L. An accelerated assay for the identification of lifespan-extending interventions in Drosophila melanogaster. Proc. Natl. Acad. Sci. USA 2004, 101, 12980-12985. [CrossRef]

19. Valenzano, D.R.; Terzibasi, E.; Genade, T.; Cattaneo, A.; Domenici, L.; Cellerino, A. Resveratrol prolongs lifespan and retards the onset of age-related markers in a short-lived vertebrate. Curr. Biol. 2006, 16, 296-300. [CrossRef]

20. Baur, J.A.; Pearson, K.J.; Price, N.L.; Jamieson, H.A.; Lerin, C.; Kalra, A.; Prabhu, V.V.; Allard, J.S.; Lopez-Lluch, G.; Lewis, K.; et al. Resveratrol improves health and survival of mice on a high-calorie diet. Nature 2006, 444, 337-342. [CrossRef]

21. Guerrero, R.F.; García-Parrilla, M.C.; Puertas, B.; Cantos-Villar, E. Wine, resveratrol and health: A review. Nat. Prod. Commun. 2009, 4, 635-658. [CrossRef]

22. Feng, J.; Liu, S.; Ma, S.; Zhao, J.; Zhang, W.; Qi, W.; Cao, P.; Wang, Z.; Lei, W. Protective effects of resveratrol on postmenopausal osteoporosis: Regulation of SIRT1-NF-kB signaling pathway. Acta Biochim. Biophys. Sin. 2014, 46, 1024-1033. [CrossRef]

23. Zhao, H.; Li, X.; Li, N.; Liu, T.; Liu, J.; Li, Z.; Xiao, H.; Li, J. Long-term resveratrol treatment prevents ovariectomy-induced osteopenia in rats without hyperplastic effects on the uterus. Br. J. Nutr. 2014, 111, 836-846. [CrossRef]

24. Wang, W.; Zhang, L.M.; Guo, C.; Han, J.F. Resveratrol promotes osteoblastic differentiation in a rat model of postmenopausal osteoporosis by regulating autophagy. Nutr. Metab. 2020, 17, 29. [CrossRef]

25. Zhang, Y.; Deng, L.; Fan, J.; Zhang, Y. Effects of resveratrol on bone metabolism and bone turnover related indexes in ovariectomized osteoporosis rats. Cell Mol. Biol. 2020, 66, 92-97. [CrossRef]

26. Zhang, Y.; Liu, M.W.; He, Y.; Deng, N.; Chen, Y.; Huang, J.; Xie, W. Protective effect of resveratrol on estrogen deficiency-induced osteoporosis though attenuating NADPH oxidase 4/nuclear factor kappa B pathway by increasing miR-92b-3p expression. Int. J. Immunopathol. Pharmacol. 2020, 34. [CrossRef]

27. Molez, A.M.; do Nascimento, E.H.L.; Haiter Neto, F.; Cirano, F.R.; Pimentel, S.P.; Ribeiro, F.V.; Casati, M.Z.; Corrêa, M.G. Effect of resveratrol on the progression of experimental periodontitis in an ovariectomized rat model of osteoporosis: Morphometric, immune-enzymatic, and gene expression analysis. J. Periodontal. Res. 2020, 55, 840-849. [CrossRef]

28. Elseweidy, M.M.; El-Swefy, S.E.; Shaheen, M.A.; Baraka, N.M.; Hammad, S.K. Effect of resveratrol and mesenchymal stem cell monotherapy and combined treatment in management of osteoporosis in ovariectomized rats: Role of SIRT1/FOXO3a and Wnt/ $\beta$-catenin pathways. Arch. Biochem. Biophys. 2021, 703, 108856. [CrossRef] 
29. Guo, D.W.; Han, Y.X.; Cong, L.; Liang, D.; Tu, G.J. Resveratrol prevents osteoporosis in ovariectomized rats by regulating microRNA-338-3p. Mol. Med. Rep. 2015, 12, 2098-2106. [CrossRef]

30. Franzoso, G.; Carlson, L.; Xing, L.; Poljak, L.; Shores, E.W.; Brown, K.D.; Leonardi, A.; Tran, T.; Boyce, B.F.; Siebenlist, U. Requirement for NF-kappaB in osteoclast and B-cell development. Genes Dev. 1997, 11, 3482-3496. [CrossRef]

31. Iotsova, V.; Caamaño, J.; Loy, J.; Yang, Y.; Lewin, A.; Bravo, R. Osteopetrosis in mice lacking NF-kappaB1 and NF-kappaB2. Nat. Med. 1997, 3, 1285-1289. [CrossRef] [PubMed]

32. Jimi, E.; Aoki, K.; Saito, H.; D’Acquisto, F.; May, M.J.; Nakamura, I.; Sudo, T.; Kojima, T.; Okamoto, F.; Fukushima, H.; et al. Selective inhibition of NF-kappa B blocks osteoclastogenesis and prevents inflammatory bone destruction in vivo. Nat. Med. 2004, 10, 617-624. [CrossRef] [PubMed]

33. Awasthi, H.; Mani, D.; Singh, D.; Gupta, A. The underlying pathophysiology and therapeutic approaches for osteoporosis. Med. Res. Rev. 2018, 38, 2024-2057. [CrossRef] [PubMed]

34. Iyer, S.; Han, L.; Bartell, S.M.; Kim, H.N.; Gubrij, I.; de Cabo, R.; O’Brien, C.A.; Manolagas, S.C.; Almeida, M. Sirtuin1 (Sirt1) promotes cortical bone formation by preventing $\beta$-catenin sequestration by FoxO transcription factors in osteoblast progenitors. J. Biol. Chem. 2014, 289, 24069-24078. [CrossRef] [PubMed]

35. Zhou, Y.; Zhou, Z.; Zhang, W.; Hu, X.; Wei, H.; Peng, J.; Jiang, S. SIRT1 inhibits adipogenesis and promotes myogenic differentiation in C3H10T1/2 pluripotent cells by regulating Wnt signaling. Cell Biosci. 2015, 5, 61. [CrossRef]

36. Puel, C.; Quintin, A.; Mathey, J.; Obled, C.; Davicco, M.J.; Lebecque, P.; Kati-Coulibaly, S.; Horcajada, M.N.; Coxam, V. Prevention of bone loss by phloridzin, an apple polyphenol, in ovariectomized rats under inflammation conditions. Calcif. Tissue Int. 2005, 77, 311-318. [CrossRef]

37. Puel, C.; Mathey, J.; Agalias, A.; Kati-Coulibaly, S.; Mardon, J.; Obled, C.; Davicco, M.J.; Lebecque, P.; Horcajada, M.N.; Skaltsounis, A.L.; et al. Dose-response study of effect of oleuropein, an olive oil polyphenol, in an ovariectomy/inflammation experimental model of bone loss in the rat. Clin. Nutr. 2006, 25, 859-868. [CrossRef]

38. Puel, C.; Mardon, J.; Agalias, A.; Davicco, M.J.; Lebecque, P.; Mazur, A.; Horcajada, M.N.; Skaltsounis, A.L.; Coxam, V. Major phenolic compounds in olive oil modulate bone loss in an ovariectomy/inflammation experimental model. J. Agric. Food Chem. 2008, 56, 9417-9422. [CrossRef]

39. Hagiwara, K.; Goto, T.; Araki, M.; Miyazaki, H.; Hagiwara, H. Olive polyphenol hydroxytyrosol prevents bone loss. Eur. J. Pharmacol. 2011, 662, 78-84. [CrossRef]

40. Sehmisch, S.; Hammer, F.; Christoffel, J.; Seidlova-Wuttke, D.; Tezval, M.; Wuttke, W.; Stuermer, K.M.; Stuermer, E.K. Comparison of the phytohormones genistein, resveratrol and 8-prenylnaringenin as agents for preventing osteoporosis. Planta Med. 2008, 74, 794-801. [CrossRef]

41. Kim, T.H.; Jung, J.W.; Ha, B.G.; Hong, J.M.; Park, E.K.; Kim, H.J.; Kim, S.Y. The effects of luteolin on osteoclast differentiation, function in vitro and ovariectomy-induced bone loss. J. Nutr. Biochem. 2011, 22, 8-15. [CrossRef] [PubMed]

42. Mundy, G.R. Osteoporosis and inflammation. Nutr. Rev. 2007, 65, S147-S151. [CrossRef] [PubMed]

43. Shen, C.L.; Wang, P.; Guerrieri, J.; Yeh, J.K.; Wang, J.S. Protective effect of green tea polyphenols on bone loss in middle-aged female rats. Osteoporos Int. 2008, 19, 979-990. [CrossRef] [PubMed]

44. Shen, C.L.; Yeh, J.K.; Stoecker, B.J.; Chyu, M.C.; Wang, J.S. Green tea polyphenols mitigate deterioration of bone microarchitecture in middle-aged female rats. Bone 2009, 44, 684-690. [CrossRef] [PubMed]

45. Shen, C.L.; Smith, B.J.; Li, J.; Cao, J.J.; Song, X.; Newhardt, M.F.; Corry, K.A.; Tomison, M.D.; Tang, L.; Wang, J.S.; et al. Effect of long-term green tea polyphenol supplementation on bone architecture, turnover, and mechanical properties in middle-aged ovariectomized rats. Calcif. Tissue Int. 2019, 104, 285-300. [CrossRef] [PubMed]

46. Dreher, I.; Schütze, N.; Baur, A.; Hesse, K.; Schneider, D.; Köhrle, J.; Jakob, F. Selenoproteins are expressed in fetal human osteoblast-like cells. Biochem. Biophys. Res. Commun. 1998, 245, 101-107. [CrossRef]

47. Kim, H.J.; Bae, Y.C.; Park, R.W.; Choi, S.W.; Cho, S.H.; Choi, Y.S.; Lee, W.J. Bone-protecting effect of safflower seeds in ovariectomized rats. Calcif. Tissue Int. 2002, 71, 88-94. [CrossRef]

48. Zhang, R.; Liu, Z.G.; Li, C.; Hu, S.J.; Liu, L.; Wang, J.P.; Mei, Q.B. Du-Zhong (Eucommia ulmoides Oliv.) cortex extract prevent OVX-induced osteoporosis in rats. Bone 2009, 45, 553-559. [CrossRef]

49. Cladis, D.P.; Debelo, H.; Lachcik, P.J.; Ferruzzi, M.G.; Weaver, C.M. Increasing doses of bueberry polyphenols alters colonic metabolism and calcium absorption in ovariectomized rats. Mol. Nutr. Food Res. 2020, 64, e2000031. [CrossRef]

50. Mei, F.; Meng, K.; Gu, Z.; Yun, Y.; Zhang, W.; Zhang, C.; Zhong, Q.; Pan, F.; Shen, X.; Xia, G.; et al. Arecanut (Areca catechu L.) seed polyphenol-ameliorated osteoporosis by altering gut microbiome via LYZ and the immune system in estrogen-deficient rats. J. Agric. Food Chem. 2021, 69, 246-258. [CrossRef]

51. Kim, B.; Lee, S.H.; Song, S.J.; Kim, W.H.; Song, E.S.; Lee, J.C.; Lee, S.J.; Han, D.W.; Lee, J.H. Protective efects of mlon extracts on bone strength, mneralization, and metabolism in rats with ovariectomy-induced osteoporosis. Antioxidants 2019, 8, 306. [CrossRef]

52. Turner, R.T.; Iwaniec, U.T.; Andrade, J.E.; Branscum, A.J.; Neese, S.L.; Olson, D.A.; Wagner, L.; Wang, V.C.; Schantz, S.L.; Helferich, W.G. Genistein administered as a once-daily oral supplement had no beneficial effect on the tibia in rat models for postmenopausal bone loss. Menopause 2013, 20, 677-686. [CrossRef] [PubMed] 
53. Ambati, S.; Miller, C.N.; Bass, E.F.; Hohos, N.M.; Hartzell, D.L.; Kelso, E.W.; Trunnell, E.R.; Yang, J.Y.; Della-Fera, M.A.; Baile, C.A.; et al. Synergistic phytochemicals fail to protect against ovariectomy induced bone loss in rats. J. Med. Food 2018, 21, 1044-1052. [CrossRef] [PubMed]

54. Cladis, D.P.; Swallow, E.A.; Allen, M.R.; Hill Gallant, K.M.; Weaver, C.M. Blueberry polyphenols do not improve bone mineral density or mechanical properties in ovariectomized rats. Calcif. Tissue Int. 2021; epub ahead of print. [CrossRef]

55. Keiler, A.M.; Zierau, O.; Bernhardt, R.; Scharnweber, D.; Lemonakis, N.; Termetzi, A.; Skaltsounis, L.; Vollmer, G.; Halabalaki, M. Impact of a functionalized olive oil extract on the uterus and the bone in a model of postmenopausal osteoporosis. Eur. J. Nutr. 2014, 53, 1073-1081. [CrossRef] [PubMed]

56. Rowland, I.; Faughnan, M.; Hoey, L.; Wähälä, K.; Williamson, G.; Cassidy, A. Bioavailability of phyto-oestrogens. Br. J. Nutr. 2003, 89 (Suppl. 1), S45-S58. [CrossRef]

57. Raisz, L.G. Pathogenesis of osteoporosis: Concepts, conflicts, and prospects. J. Clin. Investig. 2005, 115, 3318-3325. [CrossRef]

58. Richardson, S.J.; Bai, A.; Kulkarni, A.A.; Moghaddam, M.F. Efficiency in drug discovery: Liver S9 fraction assay as a sreen for metabolic stability. Drug Metab. Lett. 2016, 10, 83-90. [CrossRef] 